\title{
Implications of climate change for the water balance of the Columbia River Basin, USA
}

\author{
Danny Marks*, George A. King, Jayne Dolph** \\ ManTech Environmental Technology, Inc., U.S. EPA Environmental Research Laboratory, 200 SW 35th Street, Corvallis, \\ Oregon 97333 , USA
}

\begin{abstract}
Global climate change will affect the terrestrial biosphere primarily through changes in regional energy and water balance. Changes in soil moisture and evapotranspiration will particularly affect water and forest resources. Existing spatially lumped hydrologic models are not adequate to analyze the potential effects of climate change on the regional water balance over large river basins or regions primarily because they do not satisfactorily account for the spatial and temporal variability of hydrologic processes. Here we summarize application of a spatially distributed water balance model that was tested using historical data from the U.S. portion of the Columbia River Basin in the Pacific Northwest for a very dry (1977) and very wet (1972) water year. The model adequately partitions incoming precipitation into evapotranspiration and runoff. Because precipitation in the basin is underestimated from measured data, modeled runoff is less than measured runoff from the basin during both the wet and dry years. The potential effects of climate change on runoff and soil moisture in the Columbia River Basin were simulated using $2 \times \mathrm{CO}_{2}$ scenario data from the Geophysical Fluid Dynamics Laboratory (GFDL) general circulation model (GCM). The predicted future climate conditions significantly increase potential evapotranspiration, causing a $20 \%$ reduction in runoff relative to input precipitation, and a $58 \%$ reduction in soil moisture storage. If these changes in regional water balance are realized, the distribution and composition of forests in the Northwest would change markedly, and water resources would become more limited. Because of uncertainties in future climate scenarios, and limitations in the implementation of the water balance model, the $2 \times \mathrm{CO}_{2}$ results should be viewed only as a sensitivity analysis.
\end{abstract}

\section{INTRODUCTION}

The Intergovernmental Panel on Climate Change (IPCC) recently reported that if the projected doubling of atmospheric $\mathrm{CO}_{2}$ occurs within the next century it is likely to cause significant changes in global and regional climates, and that this will have a significant impact on ecosystems and natural resources (Houghton et al. 1990). Predicting the magnitude or direction of climate change is a complicated problem because of the numerous feedbacks and interactions between the atmosphere, oceans, and terrestrial biosphere (Dickinson 1986).

\section{Present addresses:}

- U.S. Geological Survey, Water Resources Division, Salt Lake City, Utah 84 104, USA

- Dept of Geography, University of Maryland, College Park, Maryland 20742, USA
Climate change will affect the terrestrial biosphere through changes in the regional energy balance (Dickinson 1983) and associated changes in the regional water balance (Eagleson 1986). The regional water balance consists of the partitioning of incoming precipitation into runoff and evapotranspiration from the land surface, and soil moisture storage. Seasonal shifts in water balance occur as a function of precipitation and other climate conditions. Climatic factors, such as temperature, humidity, and wind, affect the water balance by influencing evaporation and transpiration.

Changes in soil moisture and evapotranspiration are likely to have large impacts on water and forest resources, since the distribution and abundance of these resources are controlled to a large extent by the volume and seasonality of available moisture (Neilson et al. 1992). If changes in the regional water balance are significant, major shifts in vegetation patterns 
and condition are a likely result of climate change (Eagleson \& Segarra 1985, Prentice \& Fung 1990).

Changes in the regional water cycle will influence feedbacks between vegetation and climate as described in detail by Rind (1984). These influence both the magnitude and timing of climate change by altering the surface albedo and radiation balance, soil moisture storage, and evapotranspiration. The regional water balance will play a key role in future climatebiosphere interactions. The purpose of this paper is to discuss an approach for simulating the effects of climate change on regional water balance. We will focus the discussion on the rationale for developing spatially distributed water balance models, which is an expansion of previously developed water balance modeling approaches (e.g. Thornthwaite \& Mather 1955, Gleick $1987 \mathrm{a}$ ). We then summarize the current status of the development of such a model and conclude with a discussion of the application of the model for simulating the potential effects of climate change on the regional water balance in the Columbia River Basin in the Pacific Northwest of North America.

\section{RATIONALE FOR A REGIONALLY DISTRIBUTED WATER BALANCE MODEL}

The importance of water balance in determining vegetation patterns and the seasonality and volume of runoff is clear Understanding its spatial distribution is of critical importance for simulating the impacts of changing climate on vegetation and other natural resources. Consider the nature of the components of the water balance. Precipitation varies across a landscape or region as a function of regional atmospheric circulation patterns and topography. Precipitation patterns also shift temporally in a complex fashion such that one area may be relatively wet in one year or season, and relatively dry in the next. Climate change may alter regional precipitation patterns to be fundamentally different than what has occurred in the past. Soil water holding capacity, one of the key parameters affecting soil moisture, varies as a function of soil texture and depth, all of which vary spatially across a landscape Evapotranspiration also varies across a landscape as a function of temperature, humidity, wind and vegetation cover. Thus, every aspect of the regional water balance has spatial and temporal variability associated with it. In order to simulate the effects of climate change on natural resources, the spatial and temporal variability of the water balance must be characterized under the new climate conditions.

Existing hydrologic models designed to operate over large river basins or regions are not adequate to analyze the impacts of climate change on the regional water balance. These models are intended to predict changes in river flow as a function of precipitation measured at an index site. Specifically, if both precipitation and river flow are measured for a long period (15 to $40 \mathrm{yr}$ ), then the relationship between precipitation and river flow can be characterized within the range of long-term average conditions (e.g. Burnash et al. 1973). This relationship is then used to calibrate the runoff models. This type of model is of limited utility in predicting the effects of climate change on the water balance because it cannot account for spatial variation in critical water balance parameters such as precipitation, soil moisture, and evapotranspiration, and because future conditions are likely to be outside the range of the historical climatic variation used to calibrate them. Furthermore, these existing models do not predict the distribution of soil moisture, evaporation, or runoff over the basin. Parameterization and calibration of these models is not easily extended from catchment to river basin to large regional scales (Dooge 1986).

\section{REGIONAL WATER BALANCE SIMULATION}

The regionally distributed water balance model presented by Dolph et al. (1992) was designed to overcome these limitations by simulating spatial patterns of soil moisture and evapotranspiration in response to input precipitation over the Columbia River Basin under a variety of climatic conditions. The model simulates water balance at evenly spaced grid points across the basin, using precipitation and an estimate of potential evapotranspiration ${ }^{1}$ as model drivers. Evaluation of the model was based on comparing the proportional volume of estimated annual evapotranspiration and runoff to the input precipitation volume

The model is based on the following basic water balance equation which balances precipitation against runoff, evapotranspiration, and changes in soil moisture storage

$$
P=Q+E T+\Delta S
$$

where $P$ is input precipitation, $Q$ is runoff, ET is evapotranspiration, and $\Delta S$ is the change in soil moisture storage. All of the input precipitation must be partitioned into runoff, evapotranspiration, or soil moisture storage. If soil moisture storage is depleted, then the sum of runoff and evapotranspiration can exceed input precipitation; if storage is increased, the sum of runoff and evapotranspiration will be less than input precipi-

'Potential evapotranspiration is defined as the atmospheric demand for water; actual rapotranspiration is limited by the availability of water to meet the demand, and is therefore always equal to, or less than potential evapotranspiration 


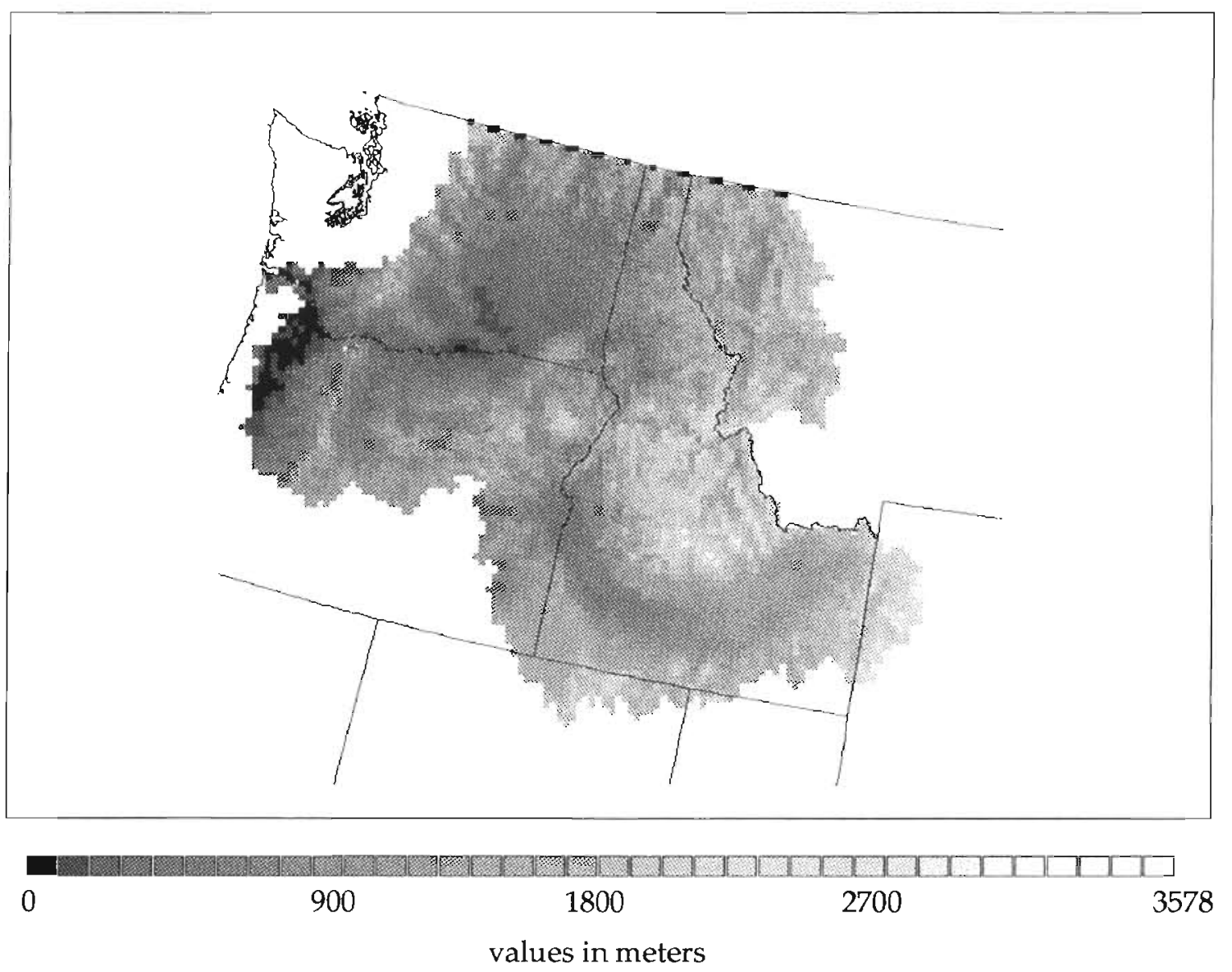

Fig. 1. Shaded elevation mage of the Columbia River Basın, northwestern U.S., using the $10 \mathrm{~km}$ dıgital elevatıon model grid

tation. The Dolph et al. (1992) model is a 'bucket' water balance model, similar to those used by several General Circulation Models (GCMs) (Jenne 1990), which treats the soil as a storage 'bucket' for precipitation in excess of evaporative and soil drainage demands. It was developed to overcome several of the problems associated with the way surface hydrologic processes are parameterized in GCMs (Eagleson 1986) by simulating the water balance for a single soil layer with drainage.

\section{Model description}

The model was used to simulate the water balance at a monthly time-step for each grid point in a $10 \mathrm{~km} \mathrm{dig-}$ ital elevation model that represented the U.S. portion of the Columbia River Basin. Fig. 1 shows this portion of the basin as a shaded contour map. The Canadian portion of the basin was excluded from this analysis because digital databases of climate, precipitation, and runoff were not available. The water balance was simulated accounting for soil drainage and evapotran- spiration losses, runoff, and soil moisture storage at every grid point. For each month, starting with the first month of the water year (October) ${ }^{2}$, water available for evapotranspiration is determined. Percent soil saturation, relative to soil water storage capacity, is calculated by adding the month's precipitation to the amount of moisture stored in the soil from the previous month. The amount of available water lost to the atmosphere through evapotranspiration is calculated as a percentage of potential evapotranspiration, using an exponential decay function that reduces evaporative effectiveness as the soil dries. If the soil is saturated, evapotranspiration is equal to potential evapotranspiration, but as the soil dries, evapotranspiration cannot exceed the water available.

\footnotetext{
${ }^{2}$ The 'water year' runs from October 1 to September 30 . It is used in place of the calendar year for hydrologic analysis in the western U.S. because climatically this region tends to have dry summers with most precipitation falling during winter (December to March). Thus the water year is more synchronized with the precipitation cycle than the calendar year
} 
Baseflow drainage (the amount of water draining from the soil into streams and rivers) is calculated using an exponential decay function of percent soil saturation that reduces baseflow as the soil dries. After evapotranspiration and baseflow demands have been satisfied, overflow (water running over the top of the bucket) is calculated as the excess available water above maximum soil water storage. Overflow only occurs if the soil is saturated with water (the bucket is full, and overflowing), after evaporative demand and baseflow have been satisfied. Runoff is then the sum of baseflow and overflow. The amount of water stored in the soil for the next month is what remains after evaparative demands are met and allowable runoff occurs. The calculated soil moisture storage is carried forward into the next month, and the procedure is repeated. Snow accumulation and ablation are not currently included in the model.

\section{Simulations for historical climate conditions}

Simulations were run for a dry (1972) and a wet (1977) water year, to evaluate how the model would respond to different climatic conditions. Precipitation data was acquired from the National Climatological Data Center (NCDC) compilation of historical precipitation measurements (EarthInfo 1990), and from the Soil Conservation Service's Snow Survey Program (SNOTEL) (USDA 1988). Because high elevation sites are under-represented in the NCDC data base, the SNOTEL data add high elevation precipitation measurements to the database. Simulations for long-term average precipitation (e.g equivalent to the $40 \mathrm{yr}$ period for which average runoff was calculated in Table 1) were not made because SNOTEL data were not available for the entire period.

Potential evapotranspiration over the basin was calculated as a function of temperature, humidity, wind, and surface roughness using a model presented by Gucinski et al. (1990). Maximum soil moisture retention capacity, the water retained in the soil between field capacity $(33 \mathrm{kPa}$ ) and wilting point (1500 kPa), was estimated using texture and organic carbon data from soil survey data (Kern 1991).

\section{Simulations for predicted $2 \times \mathrm{CO}_{2}$ conditions}

To determine the sensitivity of the regional water balance to potential future climate conditions, the regional water balance simulated under $2 \times \mathrm{CO}_{2}$ climate conditions (Houghton et al. 1990) was compared with the regional water balance simulated for the relatively wet and dry years from the historical record. Here
$2 \times \mathrm{CO}_{2}$ climate conditions are those climate conditions simulated by GCMs for an atmospheric $\mathrm{CO}_{2}$ concentration which is double that of the late 1950 s or early 1960 s (Jenne 1990). Climate variables important to the regional water balance include air temperature, precipitation, humidity, and wind speed.

Currently, the only way to produce quantitative and spatially distributed estimates of key climate variables under $2 \times \mathrm{CO}_{2}$ conditions is to use output from GCMs of the atmosphere, which are complex numerical models that simulate the fundamental physical relationships of the earth's ocean-atmosphere-land surface system. Several GCMs have been formulated. However, they differ in the way they parameterize important atmospheric and surface processes, which leads to differences in their simulations of future climate conditions and in the geographic distribution of predicted change. These inconsistencies are due, in part, to the unrealistic parameterization of land surface processes and because the computational requirements of these models limit the simulations to a very coarse grid-cell resolution (ca $4^{\circ}$ latitude $\times 5^{\circ}$ longitude). While general circulation model performance may be improved as faster computers become available, the difficulty in making future climate estimates stems from the inherent complexity of the earth's climate system and our incomplete knowledge of how that system works (Houghton et al. 1990).

Data from the Geophysical Fluid Dynamics Laboratory (GFDL) GCM (Manabe \& Wetherald 1987) was used for the $2 \times \mathrm{CO}_{2}$ sensitivity analysis because data on projected future changes in humidity and wind speed were readily available and the model has a higher spatial resolution than other GCMs for which the same data are available.

Generating a climate scenario from GCM output is complicated by the fact that the values predicted by GCM runs for $1 \times \mathrm{CO}_{2}$ (current conditions) are not consistent with historical climate data (Schlesinger 1988). To deal with this problem, ratios between the $2 \times \mathrm{CO}_{2}$ values and $1 \times \mathrm{CO}_{2}$ values were used to modify historical averages of each climate variable required in the analysis (see Parry \& Carter 1989).

\section{MODEL RESULTS}

A summary of the model run for the wet and dry years, comparing it to measured runoff from, and precipitation over, the U.S. portion of the basin is presented in Table 1 . Values are presented as an average depth of water, in $\mathrm{mm}$, over the area of the U.S. portion of the basin. Standard deviations, shown for measured precipitation and all modeled parameters, indicate the deviation from this mean depth when the parameter is distributed over the basin. No standard deviation is 
shown for measured runoff because it is derived from a single measured value at the outflow of the basin. The contribution from the Canadian portion of the basin was subtracted from the total outflow to derive the contribution from the U.S. portion.

Measured runoff from the U.S. portion of the Columbia River Basin was nearly $4 \frac{1}{2}$ times greater during the wet year (1972) than during the dry year (1977) (see Table 1). However, measured precipitation was only 1/3times greater during 1972 than during 1977, and in fact is less than the measured runoff (a physical impossibility). These results indicate that actual precipitation is severely underestimated in the basin, especially in wet years. The underestimate primarily results from the lack of high elevation measurement sites and the simple interpolation method used to distribute the measured precipitation across the spatial grid. Specifically, even with inclusion of the SNOTEL data, $30 \%$ of the area of the basin is above the nearest precipitation measurement site, and the interpolation. method does not factor in precipitation-elevation relationships. It appears that the relatively high runoff in 1972 resulted from extensive snow deposition at higher elevations in the region, and that this snow deposition was inadequately measured because of the lack of high elevation measurement sites
While precipitation values in 1972 are higher than 1977 across most of the basin (Fig. 2), the differences are not great enough to account for the differences in measured runoff between the 2 years (Table 1). During both years, the greatest precipitation fell in the Cascade mountains of Oregon and Washington, followed by the Sawtooth mountains of Idaho and Bitterroot and Rocky mountains of Montana. During the wet year (1972) more precipitation was produced in Coast Range and the Willamette Valley of Oregon than during the dry year (1977). It was considerably drier east of the Cascades and in the southern portion of the basin during 1977.

Although the modeled runoff is substantially less than that measured at the outflow of the basin for both years (Table 1), the simulated distribution of runoff is reasonable (Fig. 3). As would be expected, patterns of runoff closely follow patterns of precipitation, with most of the runoff being generated in mountainous regions and in the Willamette Valley of Oregon. During the wet year, measured snowfall in the Blue and Wallowa mountains in eastern Oregon, and in the normally arid mountains of southwestern Oregon and Idaho, was sufficient to generate significant runoff. In the dry year these regions contributed very little to discharge from the basin

Table 1. Annual water balance results for a very wet (1972) and a very dry (1977) water year, and for $2 \times \mathrm{CO}_{2}$ climate conditions predicted by the GFDL general circulation model (Manabe \& Wetherald 1987) for the U.S. portion of the Columbia River Basin. All values are in $\mathrm{mm} \mathrm{H}_{2} \mathrm{O}$ per unit area, so they represent an average depth of water over the basin. Measured annual runoff at the basin outflow has been corrected to reflect only discharge from the U.S. portion. Annual values refer to water years (Oct to following Sep). NA: data not available or not applicable. Standard deviation (SD; in parentheses) is used to indicate the extent of deviation from the basin average reported in the table; no SD is given for measured runoff from 1972 and 1977 because they are derived from single values measured at the basin outflow; SD is given for the long-term average measured runoff because it is based on 40 annual values

\begin{tabular}{|c|c|c|c|c|c|c|c|}
\hline Year & $\begin{array}{l}\text { Measured } \\
\text { annual } \\
\text { precip. }\end{array}$ & $\begin{array}{l}\text { Measured } \\
\text { annual } \\
\text { runoff }\end{array}$ & $\begin{array}{l}\text { Modeled } \\
\text { annual } \\
\text { runoff }\end{array}$ & $\begin{array}{l}\text { Annual } \\
\text { PET }\end{array}$ & $\begin{array}{l}\text { Modeled } \\
\text { annual } \\
\text { ET }\end{array}$ & $\begin{array}{c}\text { Soil } \\
\text { initial } \\
\text { storage }\end{array}$ & $\begin{array}{c}\text { Soil } \\
\text { final } \\
\text { storage }\end{array}$ \\
\hline $\begin{array}{l}\text { Wet year } \\
1972\end{array}$ & $\begin{array}{c}776 \\
(547)\end{array}$ & $1447^{\mathrm{a}}$ & $\begin{array}{c}437 \\
(475)\end{array}$ & $\begin{array}{c}878 \\
(315)\end{array}$ & $\begin{array}{c}311 \\
(151)\end{array}$ & $\begin{array}{l}65 \\
(61)\end{array}$ & $\begin{array}{c}93 \\
(60)\end{array}$ \\
\hline $\begin{array}{l}\text { Dry year } \\
1977\end{array}$ & $\begin{array}{l}507 \\
(377)\end{array}$ & $332^{\mathrm{a}}$ & $\begin{array}{c}259 \\
(295)\end{array}$ & $\begin{array}{c}898 \\
(325)\end{array}$ & $\begin{array}{c}254 \\
(150)\end{array}$ & $\begin{array}{c}65 \\
(57)\end{array}$ & $\begin{array}{c}59 \\
(63)\end{array}$ \\
\hline $\begin{array}{l}\text { Long-term } \\
\text { average }\end{array}$ & NA & $\begin{array}{l}741^{b} \\
(490)\end{array}$ & NA & NA & NA & NA & $\mathrm{NA}$ \\
\hline $\begin{array}{l}\text { GFDL } 2 \times \mathrm{CO}_{2} \\
\text { Scenario }\end{array}$ & $\begin{array}{r}636^{\complement} \\
(543)\end{array}$ & NA & $\begin{array}{c}276 \\
(319)\end{array}$ & $\begin{array}{l}1627 \\
(470)\end{array}$ & $\begin{array}{c}396 \\
(215)\end{array}$ & $\begin{array}{c}63 \\
(57)\end{array}$ & $\begin{array}{c}27 \\
(37)\end{array}$ \\
\hline \multicolumn{8}{|c|}{$\begin{array}{l}\text { Annual runoff over the U.S. portion of the Columbia River Basin (Canadian portion of basin flow subtracted out) from gage } \\
\text { measurements at the basin outflow, adjusted for storage effects (USACE 1981) } \\
\text { b40-year average unit runoff for the U.S. portion of the Columbia River Basin (Canadian portion of basin flow subtracted out) } \\
\text { using historical runoff data from Wallis et al. (1991) } \\
\text { 'Average precipitation for the U.S. portion of the Columbia River Basin calculated from the } 1972 \text { and } 1977 \text { precipitation data }\end{array}$} \\
\hline
\end{tabular}



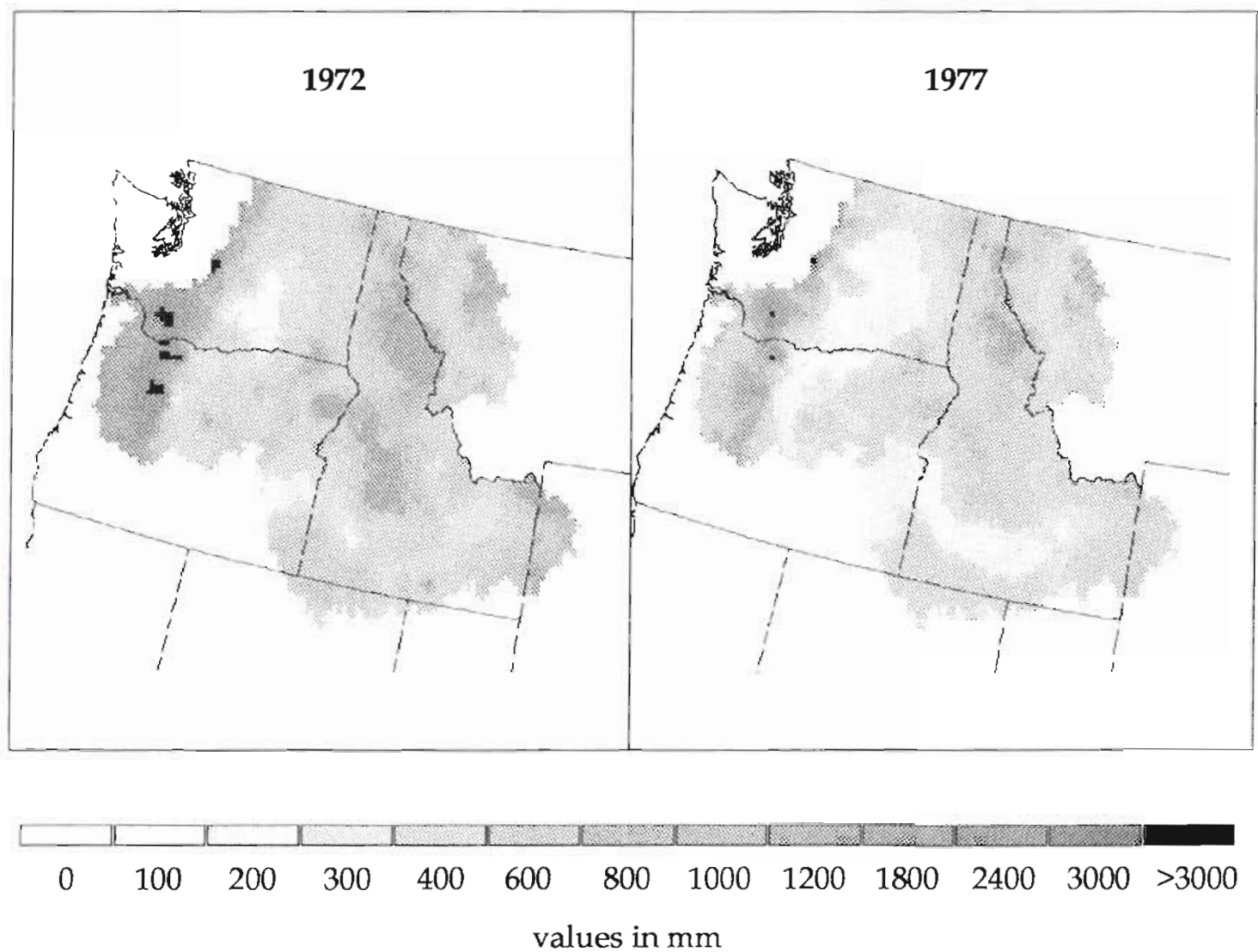

Fig. 2 Annual measured precipitation for a wet (1972) and dry (1977) water yeat, interpolated to a $10 \mathrm{~km}$ grid resolution using an inverse distance squared interpolation algorithm

Potential evapotranspuration was essentially the same for both years (Table 1), but modeled evapotranspiration was lower for the dry year (1977) than for the wet year (1972) because of soll molsture limitations resulting from reduced precipitation Though the total volume of evapotranspiration was less in the dry year. the evapotranspiration proportion of input precipitation was much higher In the wet year the model allocated $40 \%$ of input precipitation to evapotranspiration, $56 \%$ to runoff, and $4 \%$ to increased soll moisture storage. In the dry year, evapotranspiration was $50 \%$ of input precipitation. Runoff was $51 \%$ of input precipitation with the additional $1 \%$ from soil molsture storage depletion (Table 1).

Though precipitation is basically unchanged, a significantly different climate for the Columbia River Basin is predicted by the GFDL model under $2 \times \mathrm{CO}_{2}$ conditions. An average January temperature increase of $4{ }^{\circ} \mathrm{C}$ and July increase of $6.5^{\circ} \mathrm{C}$ are coupled with lower humidity and higher wind speed increasing potential evapotranspiration by about $80 \%$ over the 1972 and 1977 values (Table 1). It is important to note, however, that surface wind fields are not well pre- dicted by GCMs, so that this combination of higher temperatures, reduced humidities, and higher wind speeds form an extreme, and probably unlikely climate condition.

An average of the wet and dry year precipitation was used to simulate the water balance for the GFDLprojected $2 \times \mathrm{CO}_{2}$ conditions. With the large increase in potential evapotranspiration under $2 \times \mathrm{CO}_{2}$ conditions, the model predicted a very different water balance for the basin. Evapotranspiration becomes a much larger fraction of precipitation - $63 \%$ versus $40 \%$ for the wet year (1972) and 50\% for the dry year (1977) (Table 2) Runoff has about the same volume and distribution as for the dry year (see Table 1, Fig. 4) but when viewed as $43 \%$ of input precipitation (Table 2), proportionally represents nearly a $20 \%$ reduction in runoff from the simulated 1972 and 1977 conditions.

The 58 reduction in soil moisture storage at the end of the $2 \times \mathrm{CO}_{2}$ simulation (a reduction from 63 to $27 \mathrm{~mm}$ of water storage) is even more significant. Soil molsture depletion under the $2 \times \mathrm{CO}_{2}$ conditions contributed $13 \%$ of the predicted runoff. If these conditrons were to persist for even a few years, both soil 


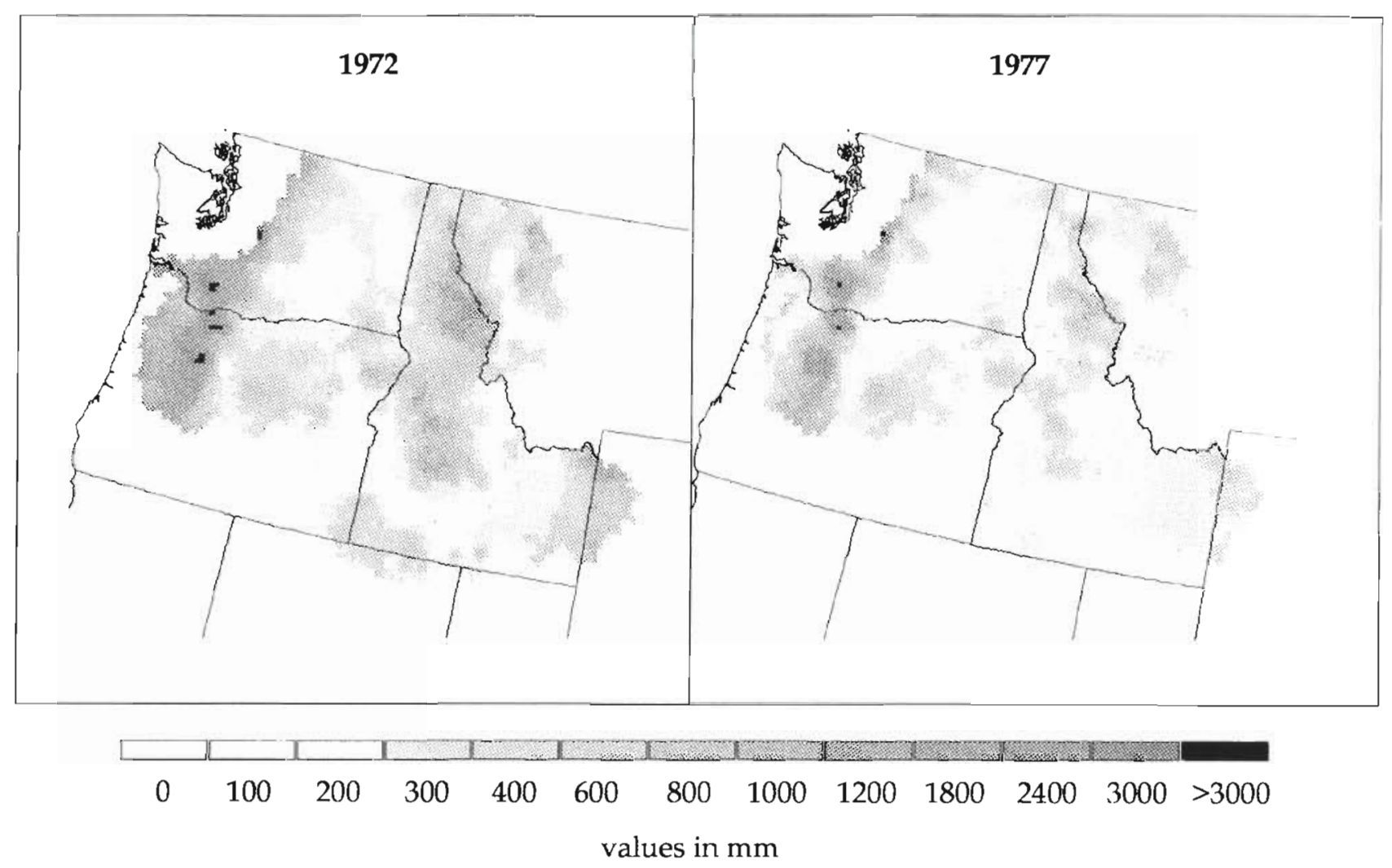

Fig. 3. Annual modeled I unotf for a wet (1972) and dry (1977) water year

Table 2. Partitioning of runoff $(Q)$, evapotranspiration $(E T)$, and change in soil water storage $(\Delta S)$ as a proportion of input annual precipitation $(P)$, for a very wet (1972), a very dry (1977), and simulated $2 \times \mathrm{CO}_{2}$ water years, over the US portion of the Columbia River Basin. The $2 \times \mathrm{CO}_{2}$ clumate condltions were predicted by the GFDL general circulation model (Manabe \& Wetherald 1987)

\begin{tabular}{|ccccc|}
\hline Year & $Q$ & $E T$ & $\Delta S$ & $P$ \\
\hline 1972 & $56 \%$ & $40 \%$ & $+4 \%$ & $100 \%$ \\
1977 & $51 \%$ & $50 \%$ & $-1 \%$ & $100 \%$ \\
$2 \times \mathrm{CO}_{2}$ & $43 \%$ & $63 \%$ & $-6 \%$ & $100 \%$ \\
\hline
\end{tabular}

moisture storage and runoff would be sharply reduced across the basin.

\section{DISCUSSION}

Dolph et al. (1992) state the limitations of measured precipitation within the Columbia River Basin, Indicating that they do not expect modeled runoff to equal measured runoff from the basin, because the precipita- tion estimates are significantly less than what actually occurred in both the wet and dry years. Model performance should, instead, be evaluated on how it partitions input precipitation into evapotranspiration, runoff, and soll moisture storage. As discussed above. the model partitions input precipitation into $40 \%$ evapotranspiration and $56 \%$ runoff for the wet year (1972), and 50\% evapotranspiration and 48\% runoff for the dry year (1977). These values fall into the ranges estimated for temperate conferous forests by Eagleson (1986) and McNaughton (1986). While est1mates of basinwide runoff and evapotranspiration partıtıoning for the Columbla River Basin are not avallable, several point or small scale experiments have reported values of these ratios for sites within the Columbia River Basin. Harr (1977) reported that storm runoff averaged $38 \%$ of storm precipitation at a site in the H. J Andrews Expenmental Forest in the central Cascade Mountains of Oregon. Running \& Coughlan (1988) simulated the 1984 annual water balance at Seattle, Washington, near the Columbia River Basin, showing $38 \%$ runoff and $58 \%$ evapotranspiratıon. Running et al. (1989) simulated annual evapotranspiration for 1985 over 2 drainages near Flathead Lake in northwestern Montana, which is in the mountauns near the northeastern topographuc boundary of the 


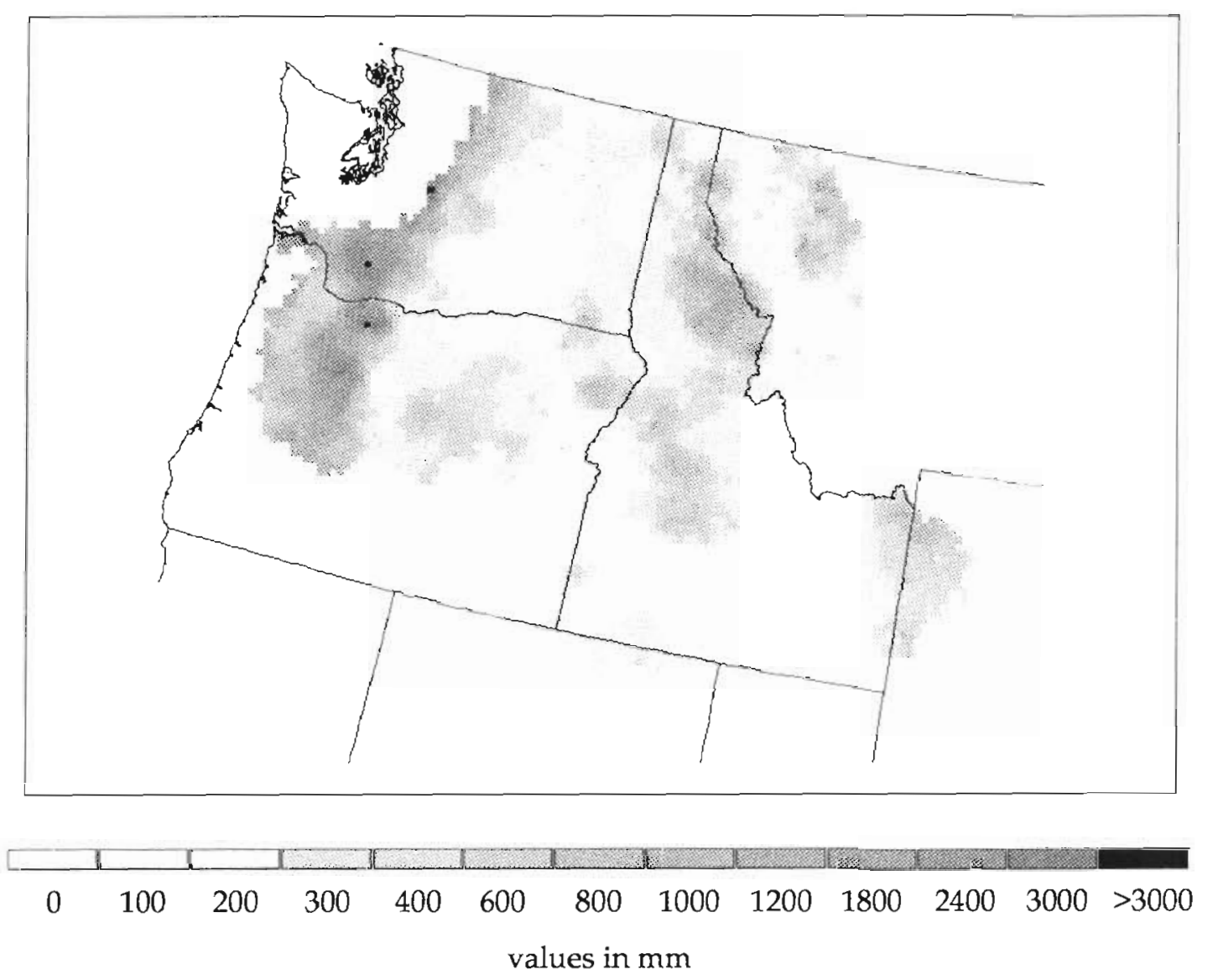

Fig. 4. Annual modeled runoff calculated using the $2 \times \mathrm{CO}_{2}$ GFDL potential evapotranspiration estimates and the average of precipitation from the wet (1972) and dry (1977) water years

Columbia River Basin. They showed runoff $60 \%$ and evapotranspiration $40 \%$ of annual precipitation in one drainage and $71 \%$ and $32 \%$ in the other. Each of these studies was for a particular site within or near the Columbia River Basin, and should not be expected to represent the regional average. However, the Dolph et al. (1992) simulation over the $10 \mathrm{~km}$ grid in the Flathead Lake region produced $75 \%$ runoff and $21 \%$ evapotranspiration for the wet year (1972), and $52 \%$ runoff and $48 \%$ evapotranspiration for the dry year (1977)

All of the studies being compared with the Dolph et al. (1992) results were run at a daily or on a storm event basis. However, while monthly results reported in Table 2 are not identical to these reported values, they are similar and give us confidence that our model is effectively partitioning input precipitation into runoff, evapotranspiration, and soil moisture storage.

The Dolph et al. (1.992) water balance model and climate change simulations can be compared with those of Gleick (1987a, b). Gleick (1987a) developed a spatially lumped water balance model for the Sacramento
River Basin in California. The principal difference between the 2 models is that Gleick's is spatially lumped, and cannot simulate patterns of soil moisture over the region. The Dolph et al. (1992) model was designed to be spatially distributed and run over a DEM grid in order to analyze patterns of soil moisture in response to different climate conditions. Gleick's (1987a) model did account for snow accumulation and ablation, and was able to better reproduce the seasonality and magnitude of runoff from the basin.

Gleick (1987b) used his water balance model to investigate the potential impacts of climate change on the Sacramento River Basin, using hypothetical GCMbased climate scenarios. His results for the GFDLbased scenarios show decreases in summer soil moisture by between 33 and $36 \%$, depending on the scenario, and a shift in the seasonality of runoff from spring to winter. This agrees with the decrease in soil moisture simulated by Dolph et al. (1992) but is of slightly lower magnitude primarily because the method that Gleick used to estimate potential evapotranspiration did not account for the coupled effects of 
reduced humidity and increased wind speed with elevated temperatures.

\section{Model limitations and future enhancements}

Use of this model to support development of management policy to reduce the impact of climate change on water resources and vegetation is limited principally by underestimation of input precipitation over the region. This is the primary cause of the difference between modeled and measured annual runoff volume. High elevation precipitation and snow measurement are especially lacking. Inclusion of SNOTEL data increases estimated precipitation volume by as much as $45 \%$ in some areas of the western USA (Dolph \& Marks 1992), but this is still insufficient in the Columbia River Basin where nearly $30 \%$ of the land area is above precipitation measurement sites. Thus far, techniques which are computationally feasible have not been developed to interpolate precipitation based on precipitation-elevation relationships across regions this large (Phillips et al. 1992). Use of the model to evaluate the effects of climate variation and change on water resources and vegetation will require spatially distributed precipitation estimates that account for the spatial arrangement of measurement sites, precipitation-elevation relationships, and topographic constraints on precipitation distribution.

Water resource planning in the Columbia River Basin is based on an estimate of the timing and magnitude of spring snowmelt. Managing water resources under a changing climate will require assessment of seasonal changes in the regional water balance. Currently the Dolph et al. (1992) model is limited to annual analyses because it does not partition precipitation into snow and rain, and thus does not simulate snow accumulation or snowmelt. The effects of climate change on water resources and the water balance of the region may involve considerable changes in the seasonality of precipitation and runoff (Gleick $1987 \mathrm{~b}$, Lettenmaier \& Gan 1990). To account for seasonal variations in soil moisture storage, runoff, and evapotranspiration, the model must include snow accumulation and depletion to simulate snow storage and spring snowmelt.

Vegetation condition and distribution are closely coupled to the regional water balance. Assessment of climate change effects on different types of vegetation requires knowledge of soil moisture status in several soil layers. Major plant lifeforms (e.g. deciduous trees, shrubs, grasses) have different overall moisture requirements, and different rooting depths which impart adaptive abilities and liabilities in relation to obtaining sufficient moisture under different precipita- tion regimes. These to a large degree control the geographic patterns of vegetation in the Columbia River Basin and elsewhere (Neilson et al. 1992). To be an effective management tool, the model must be modified to account for the effect of vegetation/water balance interaction, and the treatment of soil moisture storage must be expanded to include multiple soil layers. These are short-term research goals (Dolph et al. 1992, Neilson et al. 1992) and will yield more realistic and biologically accurate predictions of changes in vegetation distribution and condition in response to climate change.

Including vegetation characteristics such as canopy structure in the model would also improve its simulation of water balance, since evapotranspiration is primarily a water flux through a vegetation canopy controlled by stomatal conductance and canopy density (Woodward 1987). The water balance simulation will also be expanded to include the Canadian portion of the basin. This will require development of several input data layers for the Canadian region, including precipitation, temperature, humidity, wind, vegetation, and soils.

The model results using the $2 \times \mathrm{CO}_{2}$ scenario should be viewed as a sensitivity analysis rather than a prediction of future water balance in the Northwest because of the limitations of general circulation models (Houghton et al. 1990) and because of previously discussed limitations of input precipitation data and of the way the water balance model characterizes snow, soil moisture storage, and vegetation. For a more detailed analysis of potential $2 \times \mathrm{CO}_{2}$ climate impacts on the water balance of the Columbia River Basin, scenarios from several general circulation models should be used to generate a range of possible future conditions, as was done by Lettenmaier \& Gan (1990) for California. However, significant improvements must be made in GCMs before their simulations of future regional climate conditions can be considered accurate for predictive purposes.

\section{POTENTIAL IMPACTS OF CLIMATE CHANGE ON NATURAL RESOURCES}

Some qualitative statements on the impacts of climate change on natural resources in the Columbia River Basin can be made based on the preliminary output from the model and our general understanding of how climate controls the quality and quantity of water and forest resources in the basin. Gucinski et al. (1990) showed in some detail that several GCM scenarios predict an increase in potential evapotranspiration for the Columbia River Basin. Warmer temperatures, combined with increases in wind and decreases in humid- 
ity, will increase potential evapotranspiration over the region. This will increase the relative magnitude of evapotranspiration in the water balance (Tables $1 \& 2$ ). If precipitation does not increase to satisfy the increased atmospheric demand for water, soil moisture and runoff will decrease. Warmer temperatures would also shift the seasonality of runoff, with peak runoff occurring earlier in the spring (Gleick 1987b, Lettenmaier \& Gan 1990). The most significant result of the water balance simulation for $2 \times \mathrm{CO}_{2}$ climate conditions is the $58 \%$ reduction in soil moisture storage at the end of the simulation run. If the scenario climate conditions continued for even a few years, they would have a negative impact on available water resources for irrigation, urban and industrial uses, fisheries, power generation and navigation.

Although only limited modeling of climate change impacts on vegetation in the Columbia River Basin has been conducted to date, climate-induced reduction in soil moisture and an increase in the elevation of the seasonal snow zone would have a significant effect on vegetation condition and distribution in the basin. These environmental changes are likely to result in the upward migration of tree and other plant species, reduced forest productivity, and increased disturbance probabilities (Franklin et al. 1991)

\section{ROLE OF REGIONAL WATER BALANCE MODELS IN NATURAL RESOURCE MANAGEMENT}

A key component in natural resource management is understanding how resources respond to seasonal and annual variations in climate. The potential for large changes in regional climate underscores the need for understanding how climate affects resource abundance and distribution, and the need for tools with which to evaluate the potential effects of climate change on natural resources. The development of regionally distributed water balance models will enable integrated assessments of climate change impacts throughout large river basins. These models will provide a better understanding of how inter-annual shifts in precipitation patterns can affect local-scale runoff and soil moisture. Moreover, these models are an important step in developing improved vegetation models, since the water balance plays such an important role in controlling vegetation patterns. With coupled water balance-vegetation models, resource managers can assess geographical aspects of vegetation change, and may be able to predict changes in habitat type and location for biodiversity analyses.

The modeling approach presented by Dolph et al. (1992) and discussed here is an important step toward development of a simulation tool that will improve assessment of climate change impacts on water and vegetation resources. Effective implementation of this tool for resource management will be contingent upon development of improved methodologies for estimating precipitation over rugged terrain, and enhancement of the model as discussed above.

Acknowledgments. The research described in this manuscript has been funded by the U.S. Environmental Protection Agency. This document has been prepared at the EPA Environmental Research Laboratory in Corvallis, Oregon, through contract 68-C8-0006 with ManTech Environmental Technology Incorporated. It has been subjected to the Agency's peer and administrative review process, and approved for publication. Mention of trade names or commercial products does not constitute endorsement or recommendation for use.

\section{LITERATURE CITED}

Burnash, R., Ferral., R., McGuire, R. (1973). A generalized streamflow simulation system. Technical Report, Joint Federal-State River Forecast Center, Sacramento, CA

Dickinson, R. E. (1983). Land surface processes and climate surface albedos and energy balance. Adv. Geophys. 25 $305-353$

Dickinson, R. E. (1986). How will climate change? The climate system and modelling of future climate. In: Bolin, B., Doos, B. R., Jager, J., Warrick, R. A. (eds.) The greenhouse effect, climatic change, and ecosystems. Scope 29, Wiley, Chichester, p. 207-270

Dolph, J., Marks, D. (1992). Characterizing the distribution of precipitation over the continental United States using historjcal data. Clim. Change 22: 99-121

Dolph, J., Marks, D., King, G. A. (1992). Sensitivity of the regional water balance in the Columbia River Basin to climate variability: application of a spatially distributed water balance model. In: Naiman, R. J., Sedell, J. R. (eds.) New perspectives for watershed management: balancing long-term sustainability with cumulative environmental change. Springer-Verlag, New York, p. 233-265

Dooge, J. C. (1986). Looking for hydrologic laws. Water Resour. Res. 22: 46S-58S

Eagleson, P. S. (1986). The emergence of global-scale hydrology. Water Resour. Res. 22: 6S-14S

Eagleson, P. S., Segarra, R. 1. (1985). Water-limited equilibrium of savanna vegetation systems. Water Resour. Res. 21. $1483-1493$

Earthinfo Inc. (1990). Hydrodata users manual: USGS dally and peak flows. U.S. West Optical Publishing, Denver, CO

Franklin, J. F., Swanson, F. J., Harmon, M. E., Perry, D. A., Spies, T. A., Dale, V. H., McKee, A., Ferrell, W. K, Gregory, S. V., Lattin, J. D., Schowalter, T D., Larsen, D., Means, J. E. (1991). Effects of global climate change on forests in northwestern North America. NW Environ. J. 7. 233-254

Gleick, P, H. (1987a). The development and lesting of a water balance model for climate impact assessment: modeling the Sacramento Basin. Water Resour. Res. 23: 1049-1061

Gleick, P. H. (1987b). Regional hydrologic consequences of increases in atmosphenc $\mathrm{CO}_{2}$ and other trace gases. Clim. Change 10: 137-161

Gucinski, H., Marks, D., Turner, D. P. (1990). Biospheric feedbacks to climate change: the sensitivity of regional trace gas emissions, evapotranspiration, and energy balance to 
vegetation redistribution. Technical Report, U.S. Environmental Protection Agency, Environmental Research Laboratory, Corvallis, OR

Harr, R. D. (1977). Water flux in soil and subsoil on a steep forested slope. J. Hydrol. 33: 37-58

Houghton, J. T., Jenkins, G. J., Ephraums, J. J. (eds.) (1990). Climate change: the IPCC scientific assessment. Cambridge University Press, Cambridge

Jenne, R. L. (1990). Data from climate models; the $\mathrm{CO}_{2}$ warming National Center for Atmospheric Research, Boulder, $\mathrm{CO}$

Kern, J. S. (1991). Global geography of soll carbon and water holding capacity. Agronomy Abstracts, 314. American Society of Agronomy, Crop Science Society of America, Soil Science Society of America

Lettenmaier, D. P., Gan, T. Y (1990). Hydrologic sensitivities of the Sacramento-San Joaquin River Basin, California, to global warming. Water Resour. Res. 26: 69-87

Manabe, S., Wetherald, R. T. (1987). Large-scale changes in soil wetness induced by an increase in carbon dioxide. J. Atmos. Sci. 44: 1211-1235

McNaughton, K. G. (1986). Regional evaporation models. In: Rosenzweig, C., Dickinson, R. E. (eds.) Climate vegetation interactions. Office for Interdisciplinary Earth Studies (OIES) and University Corporation for Atmospheric Research (UCAR), Boulder, CO. p. 103-106

Neilson, R. P., King, G. A., Koerper, G. (1992). Toward a rulebased biome model. Lands. Ecol. 7: 27-43

Parry, M. L., Carter, T. R. (1989). An assessment of the effects of climatic change on agriculture. Clim. Change 15: $95-116$

Phillips, D. L., Dolph, J, Marks, D. (1992). A comparison of geostatistical procedures for spatial analysis of precipitation in mountainous terrain. Agric. For. Meteorol. 58: 119-141

Prentice, K. C., Fung, I. Y (1990). The sensitivity of terrestrial carbon storage to climate change. Nature 346: 48-51
Rind, D. (1984). The influence of vegetation on the hydrologic cycle in a global climate model. In: Hansen, J. E., Takahashi. T. (eds.) Climate processes and climate sensitivity. Geophys. Monogr., American Geophysical Union, Washington, DC, 5: 73-92

Running, S. W., Coughlan, J. C (1988). A general model of forest ecosystem processes for regional applications. I. Hydrologic balance canopy gas exchange and primary production processes. Ecol. Model. 42 : $125-154$

Running, S. W., Nemani, R. R., Peterson, D. L., Band, L. E., Potts, D. F., Pierce, L. L., Spanner, M. A. (1989). Mapping regional forest evapotranspiration and photosynthesis by coupling satellite data with ecosystem simulation. Ecology 70: 1090-1101

Schlesinger, M. E. (1988). Quantitative analysis of feedbacks in climate model simulations of $\mathrm{CO}_{2}$-induced warming. In: Schlesinger, M. E. (ed.) Physically-based modelling and simulation of climate and climatic change, mathematical and physical sciences. NATO ASI Series, Kluwer Publishers, Boston, 243: 653-737

Thornthwaite, C. W., Mather, J. R. (1955). The water balance. Publications in Climatology, Laboratory of Climatology, Vol. 8. Centerton, NJ

U.S. Army Corps of Engineers (1981). Adjusted streamflow and storage, 1928-1978, Columbia River and Coastal Basins. Columbia River Water Management Group, USACE, Portland, OR

U.S.D.A. Soil Conservation Service (1988). Snow survey and water supply products reference. USDA-SCS Western National Technical Center, Portland, OR

Wallis, J. R., Lettenmaier, D. P., Wood, E. F. (1991). A daily hydro-climatological data set for the continental United States. Water Resour. Res. 27: 1657-1664

Woodward, F. I. (1987). Climate and plant distribution. Cambridge University Press, New York

Manuscript first received: September 20, 1992

Revised version accepted: February 15, 1993 